RESEARCHARTICLE

\title{
Use of Female Family and Hired Labour in Agriculture: An Empirical Study in Western Uttar Pradesh, India
}

\author{
Kavita Baliyan \\ Giri Institute of Development Studies, Lucknow, India
}

\begin{abstract}
The role of women in Indian agriculture has been highlighted in a large number of studies. However, there are only a few studies which highlight the role of household female workers in agricultural activities on their family farms. Female family workers constitute a special category of labour who are called to join in agricultural work on farm whenever demand for labour increases. They are, thus, a flexible source of labour supply. Their work is seasonal and intermittent and remains unpaid and hence unrecognized. Most of the studies of female labour in agriculture were undertaken in the early decades of the green revolution. There are few recent field studies of women participation in agriculture in India. Moreover, the earlier studies were mostly confined to wheat and rice growing regions and did not look at the labour intensive commercial crops like sugarcane. The present study seeks to fill up these gaps in literature by particularly focusing upon the role of household female workers in an agriculturally developed region specializing in sugarcane cultivation. The study is based upon an intensive field survey of 240 farm households located in the agriculturally developed western region of Uttar Pradesh, the most populous state of India. The study reveals that the contribution of women to agricultural work in the study area which specializes in sugarcane cultivation is higher than their contribution revealed by earlier studies in wheat growing northern states of Punjab and Haryana, but it is lower than their involvement in the rice growing regions of south India. The study also confirms the inverse relationship between size of holding and use of female labour observed in the earlier studies. Our findings about the work segregation by sexes are also in line with the findings of the earlier studies. The study stresses that women workers in agriculture should be given due recognition in public policy to reduce the gender gap in agriculture.
\end{abstract}

Open Access

Citation: Baliyan, K. Use of Female Family and Hired Labour in Agriculture: An Empirical Study in Western Uttar Pradesh, India. Gender and Women's Studies. 2018; 2(1):2.

Received: January 10, 2018 Accepted: July 02, 2018 Published: July 17, 2018

Copyright: ( 2018 Baliyan, K. This is an open access article distributed under the terms of the Creative Commons Attribution License, which permits unrestricted use, distribution, and reproduction in any medium, provided the original author and source are credited.

Corresponding author: Kavita Baliyan, Giri Institute of Development Studies, Lucknow, India E-mail: kavitaujjwal.baliyan@gmail.com

\section{Keywords}

Female work participation rate, agricultural labour, intermittent, unpaid labour

\section{Introduction}

Since the publication of Easter Boserup's (Boserup 1970) seminal study nearly fifty years ago, there has been a growing realization among researchers about the important role womenplay in agriculture in the developing countries. Women comprise 43 percent of the agricultural labour force in developing countries, on average, ranging from about 20 percent in Latin America to almost 50 percent in Eastern and Southeastern Asia and sub-Saharan Africa (FAO, 2011). Scholars have also noted tendency towards greater feminization of agricultural labour across countries in recent years. With male rural workers migrating in search of better opportunities, women have to share greater responsibility of agricultural work (LastarriaCornhiel, 2006). Commercialisation of agriculture and promotion of export oriented crops 
have also opened new opportunities for women to engage in agricultural activities (Deere, 2005).

The increasing role played by women in agriculture is, however, not reflected in the official estimates of women workers. The main reason for the non-recognition of the continued high participation of women in agriculture may be found in the general Euro-centric and middleclass bias, according to which all women are basically seen as housewives (Mies etal., 1986). The traditional social attitudes which view women as primarily responsible for household duties also leads to undercounting of women as workers especially in case of women who work on family farms (Kanchi, 2010; Mies, 1986). The social definition of women as housewives removes them ipso facto from the perception of researchers and development planners dealing with the labour market (Mies, 1982).

In India, agriculture sector employs 65 percent of all economically active women as compared to 50 percent of men according to the Census 2011 . Nearly 28 per cent of the cultivators and 48 per cent of the agricultural labourers in the country are women. According to the NSSO Employment and Unemployment Surveys, the share of women out of the total farmers increased from 38 per cent during 1999-00 to 42 percent by 2004-05 (Srivastava \& Srivastava, 2010). However, both Census and NSS data under count the number of women workers in agriculture and the informal sector as pointed out by several scholars like Anker (1983), Sen and Sen (1985), Agarwal (1985), Sardamoni (1988), Krishnaraj (1990), Visaria (1999), Hirway (2002, 2009, 2015) and Sen (1983).

The role of women in Indian agriculture has been highlighted in a large number of studies. However, there are only a few studies which highlight the role of household female workers in agricultural activities on their family farms. The present paper is an attempt in that direction.

\section{Review of Literature}

Several studies show that women are extensively involved in agricultural activities. However, the nature and extent of women's involvement in agriculture differs in different agroproduction systems (NishuBala, 2010). Even, within a region, their involvement varies widely among different ecological sub-zones, farming system, caste, classes and socio-economic status of families (Swaminathan, 1985; Sethi, 1982; Unni, 1999; Sreekumar, 2001; Mies, 1980). Nata Duvvury (1989) observes that the extent of female participation in production in India is determined by a nexus of class/caste hierarchy and norms of patriarchal ideology. She pointed out that most peasant women do significant proportion of the work involved in pre and post-harvest operations that are done in the home compound rather than in the field. According to her while women of poor peasant households may in addition go for assisting in the field, women of households on the upper end of the hierarchy would never go for 'outdoor' work. As Dak and Sharma (1988) point out that the dominant cultural norms accept women's manual work on the family farm but working for others is considered to bring about a lowering of this status. The taboo against women's outside work is stronger among the higher castesas compared to the backward castes, scheduled castes and scheduled tribes. Martha Chen (1989) also observes that there are marked differences in women's agricultural work according to agro-ecologic zones. In general, female labour force participation rates are lower in the wheat growing belt of the north-west relative to the rice growing eastern and southern states. Variations are also observed in participation of female labour in agriculture between different rice growing regions (Agarwal, 2004; Sen, 1987).

Several studies show that household women spent long hours on agricultural work in addition to their household duties. Chakravorthy (1975) found that an active farm woman spends around 8 to 9 hours on the farm during the peak agricultural season, 3 to 4 hours on taking care of the cattle and 3 to 4 hours on their household chores. According to Agarwal (1983) women devoted $17 \%, 68 \%$ and $15 \%$ of their work time to agriculture, animal husbandry and supportive activities respectively. Singh and Bhati (1985) point out that on an average, a female worker devoted 4.2 hours of work per day on marginal farms, 4.1 hours on small farms and 3.6 hours on medium size farms. Maria Mies (1985) in her study of the role of women in subsistence production and agriculture labour in three villages of Andhra Pradesh finds that although the poor peasant and agricultural labourer women had virtually no control over land and other means of production, they carried out 70-80 percent of all field work in agricultural production. 
Narasimha Reddy and Venkatanarayana (2013) have examined the changing nature of labour use in rice cultivation in the state Andhra Pradesh. Using NSS data they show that the number of females self-employed in agriculture has declined from 10.6 million in 1993-94 to 7.7 million in 2009-10. There was a sharp increase in casual labour engaged in agriculture. Family and casual labour used for per hectare of rice cultivation has also shown a declining trend in Andhra Pradesh during the period 1990-91 and 2009-10. The trend in gender-wise labour use in rice cultivation in Andhra Pradesh between 2005 and 2011 indicate that both the male and female labour use is declining. However, the rate of decline is relatively faster with respect female labour than that of male counterpart. Two operations that have shown a noticeable decline in their share during the period are harvesting and threshing/winnowing. Increasing mechanisation of female labour intense operations such as harvesting could be possible explanation for the declining share of female labour in rice cultivation.

A number of scholars have attempted to estimate the economic contribution of women in agricultural work (Mencher and Saradamony (1982), Sen and Sen (1985), Muller (1985), Patnaik and Sailabala Debi (1986), Patel (1989), K. Saradamoni (1989), Usha Tuteja (2000). These studies pointed out that women labour contribute more in terms of time, output and income and they need a fair deal both in socio-economic planning and in decision-making

A number of studies have explored the determinants of female participation in agriculture. The studies suggested that participation amongst women is affected by various cultural and social factors (Chowdhry, 1993; Duvvury, 1989). Factors like literacy; caste and age also affect women's participation in agricultural work (Arya \& Madhukar, 1988; Dutta \& Sharma, 1985; Srivastava \& Srivastava, 2010;Baliyan, 2014). Role of economic factors i.e., land holding status and income level of households has been highlighted by some scholars (Chakravorty, 1978; MahendraDev, 2004). Women's participation in agricultural work is also influenced by the cropping pattern (Sen, 1983; Eapen, 1994; JeemolUnni, 1999). Other studies have pointed out that the level of development of a region also affects women's participation in work (Devendra \& Chittedi, 1992; Roy, 1993).

Pattnaik et al. (2017) have examined the trends in participation of women in agriculture in India and its states using Census data. They find substantial variation in dependence on agricultural employment across states. A regression analysis across states shows that women's participation in agriculture is negatively related with the size of holding and positively related with poverty levels. They conclude that women's participation in agriculture is higher when the family and the agriculture are less advantageous for livelihoods.

Scholars have also observed sex segregation in agricultural work. Both Meis (1985) and Chen (1989) described pattern of labour use of men and women in agricultural operations. In general women labour both family and hired is employed in operations like weeding, winnowing, drying, storage, and husking or milling. The preparation and application of organic manure is also a women-dominated operation. Rice transplanting, in almost all regions, is dominated by women. On the other hand, ploughing by bullocks or tractors is exclusively done by male labour. Harvesting is carried out by both men and women. In general, the operations in which women dominate involve light work and use of simple tools. Hence the work is regarded as unskilled and is poorly paid. On the other hand, men dominate in activities which require greater physical strength (ploughing), involve use of machinery (tractors, threshers and tubewell operation) and modern technology (application of chemical fertilizers and pesticides). They also are exclusively engaged in activities involving interaction with outsiders (purchase of inputs and sale of produce). Hence, they retain control over income generated from agriculture.

According to Krishnaraj \& Shah (2014) in patriarchal societies, men are assigned those types of activity which have a direct exchange value and therefore the work of men is considered more useful and that of women is considered less prestigious in the social hierarchy. Such job segregation has several consequences for female workers as it creates a disparity in wage rate, brings down the bargaining power of women workers and reduces them to state of marginal, intermittent or reserve labour which is highly unorganized (Sunder, 1981; Mies, 1980). It has direct impact on the status of female in the family and society thereby affecting decision making power of women within the household.

In the early years of the green revolution in the country, scholars were concerned about the impact of the new technology and mechanization on female labour in agriculture. Beena Agarwal (1981) examined the impact of farm mechanization on use of different type of labour 
(family, hired, permanent and casual) in Punjab. Her study revealed low female involvement in farm work on wheat farms. Female labour on the sample farms contributed 9.8 percent of total labour time used, 87.8 percent of which was on harvesting of wheat crop. Family female labour accounted for only 1.6 percent of total farm labour and 16.3 percent of total family labour. Sowing, harvesting and threshing accounted for 28.2 percent, 30.4 percent and 32.6 percent of female labour time respectively.

Sheila Bhalla (1979) examined the impact of technological change on women workers in early phase of green revolution in Haryana. According to her, women (and children) are called upon to work generally when there is an absolute shortage of labourers, sufficient to push the wage rates up during a peak activity period, as well as specifically for certain crop operations, such as cotton picking, for which women are preferred. She reports that total labour days spent per acre in Haryana in 1972-73 were 32.3, out of which 6.6 days were provided by female labour and 4.6-persondays by unpaid female family labour.

Studies on the impact of new technology on female family labour throw up mixed results for different crops and regions. Dhillon (1980) and Achanta (1982) found the negative impact of use of technology on women participation in agriculture. On the other hand, other studies argued that due to the adoption of new technology, the use of female labour has increased enormously on all size groups of farms especially female agriculture labour (Mies 1980; Agarwal 1985; Suryawanshi \& Kapse (1985); Chand, Sidhu \& Kaul 1985). According to Davvury (1989) the employment of female family labour time rises with HYV technology on the small farms in most of the cases (Davvury, 1989).

In more recent year's studies have focused on the phenomenon of feminization of agriculture work as male workers are seeking better paid non-agricultural work or migrating to urban areas in search of job ((Tumbe, 2014; Agrawal \& Chandrasekhar, 2015; Pattanaik et al. 2017; Srivastava, 2011). This situation has affected the disadvantageous hill regions more seriously (Bhandari \& Reddy, 2015). These studies show that participation of both men and women in agriculture has declined, but the rate of decline has been faster among men than it has among women. A number of scholars have asserted that the feminization of agriculture labour should not be identified with women empowerment as it may affect them adversely in various ways (Kanchi, 2010; Pattanaik et al. 2017).

Many studies highlight the fact that inspite of their substantial role in agriculture, women workers are constrained by number of factors due to lack of ownership of land and access to inputs like credit and extension (Chen, 1989; Kanchi, 2010; Pattanaik, 2017). The lack of ownership land by women is of critical importance as it prevents them from access to credit and other facilities. Women are also neglected by the government officials in research and extension. Such persisting gender inequalities in access to agricultural assets, inputs, information, and services have hampered women's potential economic contributions in agriculture (FAO, 2011; World Bank, 2012).

\section{The Present Study}

Most of the studies on female labour in agriculture were undertaken in the early decades of the green revolution. Only few field studies of women participation in agriculture are available for the recent years. These studies have looked specifically at the participation of household women on agricultural work on their family farm. The female family workers constitute a special category of labour who are called to join in agricultural work on farm whenever demand for labour increases. They are, thus, a flexible source of labour supply. Their work is seasonal, intermittent, remains unpaid and hence unrecognized. Moreover, the earlier studies were mostly confined to wheat and rice growing regions and did not look the labour intensive commercial crops like sugarcane. The present study seeks to fill up these gaps in literature by particularly focusing upon the role of household female workers in an agriculturally developed region specializing in sugarcane cultivation.

The present paper examines the role that household women play in agricultural activities on their family farms. In particular it examines the following questions:

(I) What is the extent of women's participation in agriculture activities on their family farms?

(ii) Does female participation vary for different crops?

(iii) What are the activities in which women participate to a greater extent? 
(iv) Does level of women participation vary on different size holdings?

(v) What is the overall contribution of family female labour in total labour use on family farms?

The study is based upon an intensive field survey of 240 farm households belonging to Muzaffarnagar and Baghpat districts located in the agriculturally developed western region of Uttar Pradesh, the most populous state of India. This region was selected because it is an agriculturally developed region with a higher degree of mechanization. It also specializes in the cultivation of sugarcane, a labour intensive crop.

A multi-stage sampling design was adopted for selection of the households for the study. In the first stage, two districts of western UP (Muzaffarnagar and Baghpat) were selected purposely as they have similar cropping pattern as that of the region, which specializes in cultivation of sugarcane and wheat crops. In the second stage, two blocks were selected from each district with larger area under these two crops. Then, two villages were randomly selected from the four selected blocks. In the final stage, we selected 30 cultivating households randomly for field survey from each village representing the different size classes of land holdings.

The primary survey was conducted by the researcher herself during the year 2008-09. The researcher comes from an agricultural family from the same region and is familiar with the study area. Interviews were conducted with the senior female family members of the sample households and the male head of the family. The interviews were conducted in the regional language (Hindi). During the field survey, detailed information was collected about time spent by different family members and hired labourers on agricultural activities, animal husbandry and domestic work. The responses were based upon the recall by the respondents. Hence an element of recall error is present in the responses. However, most of the studies of labour use in agriculture follow the same methodology.

The analysis presents data on labour use by category of labour, i.e. male and female labour sub-divided into family and hired labour. This enables us to see the contribution of female labour (family and hired) in overall labour use in agriculture. Since the intensity of labour use differs for different crops, the findings of three crops are presented separately, namely sugarcane, wheat and other crops taken together. As female participation tends to vary from activity to activity, the results are presented activitywise, which helps us to capture work segregation by sex. The issue of the relation between women participation in agriculture and size of holdings has also been probed.

The discussion begins with a brief presentation of the salient agro-economic features of the study area.

\section{The Study Area}

Muzaffarnagar and Baghpat are among the richest districts of U.P. Per capita income of Baghpat was Rs. 51,636 and Rs. 43,764 in Muzaffarnagar district in 2012-13 as compared to per capita income of Rs. 33,137 in the state as a whole(Planning Department UP Government 2013). Table 1 shows the land use pattern in the two districts. Over three-fourths of the land area in the districts is under cultivation. Almost the entire cultivated area is under irrigation in the two districts. Tube-wells are the main source of irrigation supplemented by canals. The region is more mechanized and has double intensity of tractors per cropped area as compared to the state average. Cropping intensity is 150 and 161 in Muzaffarnagar and Baghpat respectively. This is so because the two districts specialize in growing sugarcane which is a long duration crop. The average size of a holding in both the districts is small(around 1 ha against the state average of $0.80 \mathrm{ha}$ ). The study area is known for its mixed farming pattern with animal husbandry as an important subsidiary industry. 
Table 1. Land use characteristics of the study area, 2013-14

\begin{tabular}{|l|c|c|c|}
\hline \multicolumn{1}{|c|}{ Indicators } & Muzaffarnagar & Baghpat & Uttar Pradesh \\
\hline Net area sown as \% of total area & 74.64 & 80.00 & 68.67 \\
\hline Per capita net area sown (ha.) & 0.05 & 0.08 & 0.08 \\
\hline Cropping intensity & 144.76 & 162.16 & 156.51 \\
\hline Percentage of net irrigated area & 98.80 & 100.00 & 84.8 \\
\hline $\begin{array}{l}\text { Percentage of net irrigated area by } \\
\text { Tube wells }\end{array}$ & 72.65 & 97.92 & 68.24 \\
\hline Average size of holdings (ha.) (2010-11) & 0.95 & 0.99 & 0.76 \\
\hline $\begin{array}{l}\text { No. of Tractors per 1000 Ha. of gross area } \\
\text { Sown (2007) }\end{array}$ & 81 & 69 & 29 \\
\hline $\begin{array}{l}\text { Net area sown per hundred of Livestock } \\
\text { (2009-10) }\end{array}$ & 27.95 & 20.42 & 25.93 \\
\hline Population per milch cattle 2012 19 $9^{\text {th }}$ census & 9.11 & 5.75 & 9.80 \\
\hline
\end{tabular}

Source: Compiled from Statistical Abstract, Uttar Pradesh, 2015 and District Level Development Indicators (Annual) 2017, Economics and Statistics Division, State Planning Institute UP, Lucknow

Table 2 shows the demographic indicators of the two selected districts. Muzaffarnagar district had a population of 4.1 million in 2011, while Baghpat had a population of 1.3 million. The sex ratio is adverse in both the districts. The literacy rate of Baghpat district was 72.0 percent and Muzaffarnagar district has a literacy rate of 69.1 percent against the literacy rate of 67.7 percent in UP in 2011. Female literacy is markedly lower than male literacy in both the districts. The female work participation rate is also very low in the study area, only about 10-12 percent including main and marginal workers as per Census in 2011. About 55-56 percent of female workers are main workers (who work for more than 180 days in a year).

Table 2. Demographic indicators of the study area

\begin{tabular}{|l|l|c|c|c|c|c|c|}
\hline \multirow{2}{*}{ Demographic Indicators } & \multicolumn{2}{c|}{ Muzaffarnagar } & \multicolumn{2}{c|}{ Baghpat } & \multicolumn{2}{c|}{ Uttar Pradesh } \\
\cline { 3 - 8 } & Total & Rural & Total & Rural & Total & Rural \\
\hline \multirow{3}{*}{$\begin{array}{l}\text { Population, } \\
2011\end{array}$} & (in 000) & 4144 & 2952 & 1303 & 1028 & 199812 & 155317 \\
\cline { 2 - 8 } & Sex Ratio & 889 & 886 & 861 & 856 & 912 & 918 \\
\cline { 2 - 8 } & $\begin{array}{l}\text { Child Sex } \\
\text { Ratio }\end{array}$ & 863 & 862 & 841 & 837 & 902 & 906 \\
\hline $\begin{array}{l}\text { Literacy } \\
\text { Rate, 2011 } \\
(\%)\end{array}$ & Persons & 69.12 & 68.34 & 72.01 & 73.28 & 67.68 & 65.46 \\
\cline { 2 - 8 } & Male & 78.44 & 78.71 & 82.45 & 81.54 & 77.28 & 76.33 \\
\cline { 2 - 8 } & Female & 58.69 & 56.70 & 59.95 & 63.95 & 57.18 & 53.65 \\
\hline $\begin{array}{l}\text { Total Work } \\
\text { Participation } \\
\text { Rate, } \\
2011(\%)\end{array}$ & Persons & 31.17 & 31.96 & 31.98 & 32.84 & 32.94 & 33.45 \\
\cline { 2 - 8 } & Male & 49.31 & 49.33 & 48.94 & 49.28 & 47.71 & 47.35 \\
\cline { 2 - 8 } & Female & 10.77 & 12.36 & 12.29 & 13.63 & 16.75 & 18.30 \\
\hline $\begin{array}{l}\text { Main } \\
\text { Workers as } \\
\% \text { of total }\end{array}$ & Persons & 84.04 & 73.78 & 80.28 & 74.45 & 67.82 & 64.56 \\
\cline { 2 - 8 } & Male & 88.96 & 88.12 & 85.42 & 84.51 & 75.07 & 72.52 \\
\cline { 2 - 8 } & Female & 58.68 & 56.44 & 56.50 & 55.09 & 45.19 & 42.11 \\
\hline
\end{tabular}

Source: Census of India 2011

\section{Findings and Discussion}

The data has been collected on total labour use(family and hired) by sex for the three crops groups, namely, sugarcane, wheat and other crops. In sample households, the area under these crops as percentage of gross sown area (GSA) was 54, 27 and 19 percent respectively. 
Among the three crops group, labour intensity is highest in case of sugarcane. The discussion for the three crops (given below)is presented separately so as to bring out the differences in labour use.

\section{Use of Family and Hired Labour in Sugarcane}

Sugarcane is a long duration crop. The season of sugarcane lasts from April to FebruaryMarch. It is a labour intensive crop in which both family and hired labour is used. There is a clear-cut demarcation between the work done by male and female workers. Table 3 shows average persondays per hectare put in by male and female family and hired labour in sugarcane cultivation by different activities. Eight hours of work is treated as one-person day. Total persondays spent per hectare on sugarcane cultivation come to 360 out of which 275persondays are contributed by men and 85-person days by women. Total Person-days in sugarcane crop spent by women family workers comes to 41-persondays and 42-persondays by hired women labour per hectare, while male family members spend 198-persondays and hired male labour spend 77.3 persondays.

Table 4 shows the percentage distribution of person days per hectare in different activities in sugarcane cultivation. As will be seen from the table woman's participation is largely confined to only some activities such as seed collecting, weeding, cleaning and loading as these are regarded as light activities suitable for females. Cleaning of cane accounts for 55.6 percent of total female labour and 76 percent of hired female labour spent on sugarcane cultivation and transport/loading of cane output for 17 percent. Around 17 and 8 percent of total work hours are spent on weeding by family and hired female labor respectively. Women contribution is very low in application of fertilizers and pesticides, irrigation and sale of output, which are regarded as skilled work to be performed by men. Cleaning of cane also accounts for 52.6 percent of hired male labour. About 13 percent of hired male labour is spent on transport/loading of sugarcane and 11 percent on weeding and digging. Purchase of inputs and sales of output are exclusively done by male family members only. This also allows male family members to retain control of income from the farm.

Table 3. Average persondays per hectare used in sugarcane cultivation

\begin{tabular}{|l|c|c|c|c|c|}
\hline \multirow{2}{*}{\multicolumn{1}{|c|}{ Type of Activity }} & \multicolumn{2}{|c|}{ Family Labour } & \multicolumn{2}{c|}{ Hired labour } & \multirow{2}{*}{ Total } \\
\cline { 2 - 5 } & Females & Males & Females & Males & 4.2 \\
\hline Land Preparation & 0.5 & 2.5 & 0.0 & 1.2 & 5.5 \\
\hline Dung Application & 0.5 & 3.9 & 0.0 & 1.1 & 8.1 \\
\hline Seed collecting/Cutting & 1.3 & 3.5 & 1.2 & 2.0 & 5.5 \\
\hline Irrigation & 0.3 & 3.7 & 0.0 & 1.5 & 17.4 \\
\hline Sowing & 0.4 & 14.5 & 0.0 & 2.5 & 22.9 \\
\hline Weeding & 7.1 & 8.2 & 3.2 & 4.3 & 14.1 \\
\hline Digging & 1.9 & 8.7 & 0.0 & 3.5 & 4.7 \\
\hline Fertilizing & 0.1 & 3.6 & 0.0 & 1.0 & 2.7 \\
\hline Pesticide & 0.1 & 2.0 & 0.0 & 0.6 & 22.9 \\
\hline Binding of cane & 0.4 & 14.0 & 0.0 & 8.5 & 175.0 \\
\hline Cleaning of cane & 23.4 & 78.7 & 32.2 & 40.7 & 41.0 \\
\hline Loading/Transport of Cane & 5.5 & 19.7 & 5.6 & 10.2 & 3.7 \\
\hline Buying of Inputs & 0.2 & 3.5 & 0.0 & 0.0 & 29.4 \\
\hline Sales of crop & 0.0 & 29.4 & 0.0 & 0.0 & 2.6 \\
\hline Hiring of labour & 0.3 & 2.3 & 0.0 & 0.0 & 359.5 \\
\hline Total & 41.8 & 198.2 & 42.3 & 77.3 & \\
\hline
\end{tabular}

Source: Field survey 
Table 4.Percentage distribution of person days per hectare in sugarcane

\begin{tabular}{|l|c|c|c|c|c|}
\hline \multirow{2}{*}{\multicolumn{1}{|c|}{ Type of Activity }} & \multicolumn{2}{c|}{ Family Labour } & \multicolumn{2}{c|}{ Hired labour } & \multirow{2}{*}{ Total } \\
\cline { 2 - 5 } & Females & Males & Females & Males & 1.2 \\
\hline Land Preparation & 1.2 & 1.3 & 0.0 & 1.6 & 1.5 \\
\hline Dung Application & 1.2 & 2.0 & 0.0 & 1.4 & 2.2 \\
\hline Seed collecting/Cutting & 3.1 & 1.8 & 2.9 & 2.6 & 1.5 \\
\hline Irrigation & 0.7 & 1.9 & 0.0 & 2.0 & 4.9 \\
\hline Sowing & 1.0 & 7.3 & 0.0 & 3.3 & 6.4 \\
\hline Weeding & 17.0 & 4.1 & 7.6 & 5.6 & 3.9 \\
\hline Digging & 4.5 & 4.4 & 0.0 & 4.6 & 1.3 \\
\hline Fertilizing & 0.2 & 1.8 & 0.0 & 1.3 & 0.7 \\
\hline Pesticide & 0.2 & 1.0 & 0.0 & 0.8 & 6.4 \\
\hline Binding of cane & 1.0 & 7.1 & 0.0 & 11.0 & 48.7 \\
\hline Cleaning of cane & 56.0 & 39.7 & 76.2 & 52.6 & 11.4 \\
\hline Loading/Transport of Cane & 13.2 & 9.9 & 13.2 & 13.2 & 1.0 \\
\hline Buying of Inputs & 0.5 & 1.8 & 0.0 & 0.0 & 8.2 \\
\hline Sales of crop & 0.0 & 14.8 & 0.0 & 0.0 & 0.7 \\
\hline Hiring of labour & 0.7 & 1.2 & 0.0 & 0.0 & 100.0 \\
\hline Total & 100.0 & 100.0 & 100.0 & 100.0 & \\
\hline
\end{tabular}

Source: Based on Table 3

\section{Labour use in Wheat Crop}

Table 5 shows the persondays spent by family members and hired labour in cultivation of wheat crop by type of activity. On an average, 104-persondays are put in wheat cultivation per hectare. The contribution of female and male family members is 27.3 -persondays and 56.2persondays respectively. Hired labour contributes 20 Person-days per hectare in wheat crop. Hired casual labour is used in harvesting and threshing activity only, but permanent hired male labour is used in other activities like land preparation, dung spraying, irrigation and fertilizing and loading or carrying chaff from field to house.

Table 5. Average persondays per hectare in wheat

\begin{tabular}{|l|c|c|c|c|c|}
\hline \multirow{2}{*}{\multicolumn{1}{|c|}{ Type of Activity }} & \multicolumn{2}{c|}{ Family Labour } & \multicolumn{2}{c|}{ Hired labour } & \multirow{2}{*}{ Total } \\
\cline { 2 - 5 } & Females & Males & Females & Males & 4.1 \\
\hline Land Preparation & 0.6 & 2.4 & 0.0 & 1.1 & 6.4 \\
\hline Dung Application & 0.7 & 4.3 & 0.0 & 1.4 & 10.0 \\
\hline Irrigation & 0.1 & 8.2 & 0.0 & 1.7 & 4.3 \\
\hline Sowing & 0.7 & 2.6 & 0.0 & 1.0 & 2.7 \\
\hline Weeding & 2.7 & 0.0 & 0.0 & 0.0 & 2.3 \\
\hline Fertilizing & 0.0 & 1.2 & 0.0 & 1.1 & 1.4 \\
\hline Pesticide Spraying & 0.0 & 1.2 & 0.0 & 0.2 & 39.7 \\
\hline Harvesting & 11.6 & 20.4 & 2.6 & 5.1 & 7.3 \\
\hline Threshing & 1.5 & 3.8 & 0.4 & 1.6 & 4.2 \\
\hline Carrying Grain to house & 1.0 & 2.4 & 0.0 & 0.8 & 10.0 \\
\hline Carrying chaff to house & 2.0 & 5.2 & 0.0 & 2.8 & 4.4 \\
\hline Cleaning Grain & 3.6 & 0.0 & 0.0 & 0.8 & 3.4 \\
\hline Storage & 2.5 & 0.0 & 0.9 & 0.0 & 2.5 \\
\hline Buying of Inputs & 0.0 & 2.5 & 0.0 & 0.0 & 0.3 \\
\hline Sale of crop & 0.0 & 0.3 & 0.0 & 0.0 & 1.8 \\
\hline Hiring of labour & 0.2 & 1.6 & 0.0 & 0.0 & 104.2 \\
\hline Total & 27.3 & 56.2 & 3.9 & 16.8 & \\
\hline
\end{tabular}

\section{Source: Field Survey}

Table 6 shows the percentage distribution of male and female family labour by type of activity in wheat cultivation. Harvesting alone accounts for around 42 percent of person days in case of female family workers. Around 22 percent of female time is spent on cleaning and storage of grain and 10 per cent on weeding while time spent on other activities is nominal. In case of male family labour, harvesting accounts for 36.3 percent of persondays and irrigation 
14.6 percent of persondays. About 18 percent time is spent on harvesting and carrying grain and chaff to house. Hired female labour is used mainly in harvesting, threshing and storage of grain, while male labour is hired mainly for threshing, carrying chaff to home and irrigation. The table shows that all types of labour is involved in carrying out activities related to harvesting and threshing when the demand for labour increases substantially and the operation has to be completed in a short time. Females of the household are drawn in these activities for saving the wage cost. Cleaning and storage of grain are also female responsibility. However, buying of inputs and sale of crops are retained by the male members in their hands.

Table 6. Percentage distribution of family and hired labour in wheat by type of activity

\begin{tabular}{|c|c|c|c|c|c|}
\hline \multirow[b]{2}{*}{ Type of Activity } & \multicolumn{2}{|c|}{ Family Labour } & \multicolumn{2}{|c|}{ Hired labour } & \multirow[b]{2}{*}{ Total } \\
\hline & Females & Males & Females & Males & \\
\hline Land Preparation & 2.2 & 4.3 & 0.0 & 6.4 & 3.9 \\
\hline Dung Application & 2.6 & 7.7 & 0.0 & 8.5 & 6.2 \\
\hline Irrigation & 0.4 & 14.6 & 0.0 & 10.1 & 9.6 \\
\hline Sowing & 2.6 & 4.6 & 0.0 & 6.0 & 4.1 \\
\hline Weeding & 9.9 & 0.0 & 0.0 & 0.0 & 2.6 \\
\hline Fertilizing & 0.0 & 2.1 & 0.0 & 6.8 & 2.2 \\
\hline Pesticide Spraying & 0.0 & 2.1 & 0.0 & 1.3 & 1.4 \\
\hline Harvesting & 42.5 & 36.3 & 65.7 & 30.4 & 38.1 \\
\hline Threshing & 5.5 & 6.8 & 11.3 & 9.4 & 7.0 \\
\hline Carrying Grain to house & 3.7 & 4.3 & 0.0 & 4.7 & 4.0 \\
\hline Carrying chaff to house & 7.3 & 9.3 & 0.0 & 16.5 & 9.6 \\
\hline Cleaning Grain & 13.2 & 0.0 & 0.0 & 4.7 & 4.2 \\
\hline Storage & 9.2 & 0.0 & 23.0 & 0.0 & 3.3 \\
\hline Buying of Inputs & 0.0 & 4.4 & 0.0 & 0.0 & 2.4 \\
\hline Sale of crop & 0.0 & 0.5 & 0.0 & 0.0 & 0.3 \\
\hline Hiring of labour & 0.7 & 2.8 & 0.0 & 0.0 & 1.7 \\
\hline Total & 100.0 & 100.0 & 100.0 & 100.0 & 100.0 \\
\hline
\end{tabular}

Source: Based on Table 5

\section{Use of Labour in Other Crops}

The sample farmers grow a number of other crops like mustard, potato, rice, gram, millets, etc. However, area put under these crops is very small and output is mainly for household consumption. Generally, these crops are grown in the zaid (rainy season). The labour used in these crops has been analyzed together. Table 7 shows persondays spent on cultivation of other crops per farm. On average 118-persondays are used in cultivation of other crops. Female family members spend on average 23 person-days in cultivation of other crops, while male family workers spend on 86.5-persondays per hectare. Hired labour is mainly used in transplantation and harvesting of paddy. A female hired labour puts in around 4-persondays of work on these crops, while a male hired labour puts in about 5-persondays. Use of hired labour for these crops is low as these are mainly subsistence crops grown for home consumption. 
Table 7. Average person-days of family and hired labour in other crops per hectare

\begin{tabular}{|l|c|c|c|c|c|}
\hline \multirow{2}{*}{\multicolumn{1}{c|}{ Type of Activity }} & \multicolumn{2}{c|}{ Family Labour } & \multicolumn{2}{c|}{ Hired labour } & \multirow{2}{*}{ Total } \\
\cline { 2 - 5 } & Females & Males & Females & Males & 8.7 \\
\hline Land Preparation & 1.3 & 6.6 & 0.0 & 0.8 & 1.4 \\
\hline Dung Application & 0.0 & 0.9 & 0.3 & 0.2 & 9.0 \\
\hline Irrigation & 0.0 & 8.8 & 0.0 & 0.2 & 8.4 \\
\hline Sowing & 1.5 & 6.9 & 0.0 & 0.0 & 11.0 \\
\hline Weeding & 5.1 & 5.5 & 0.2 & 0.2 & 3.4 \\
\hline Transplanting of paddy & 0.4 & 0.3 & 2.1 & 0.6 & 65.3 \\
\hline Harvesting & 12.7 & 51.4 & 0.8 & 0.4 & 7.7 \\
\hline Threshing & 1.5 & 2.8 & 0.8 & 2.6 & 2.1 \\
\hline Buying of Inputs & 0.5 & 1.6 & 0.0 & 0.0 & 0.4 \\
\hline Sale of crop & 0.0 & 0.4 & 0.0 & 0.0 & 1.4 \\
\hline Hiring of labour & 0.0 & 1.4 & 0.0 & 0.0 & 118.4 \\
\hline Total & 23.0 & 86.5 & 4.0 & 5.0 & \\
\hline
\end{tabular}

Source: Field Survey

Table 8 shows the percentage distribution of labour use in all other crops by type of activity. Over 55 percent of female family labour on other crops is spent on harvesting and 22.5 percent on weeding. Male family workers spend 59.5 percent of their labour time on harvesting and 10 per cent on irrigation of other crops. In case of hired female labour, 54 percent time is spent on transplanting of paddy and about 40 percent on threshing and harvesting. Male hired workers spend about half of their time on threshing and another one-sixth on land preparation.

Table 8. Percentage distribution of family and hired labour in other crops

\begin{tabular}{|l|c|c|c|c|c|}
\hline \multirow{2}{*}{\multicolumn{1}{|c|}{ Type of Activity }} & \multicolumn{2}{c|}{ Family Labour } & \multicolumn{2}{c|}{ Hired labour } & \multirow{2}{*}{ Total } \\
\cline { 2 - 5 } & Females & Males & Females & Males & 7.3 \\
\hline Land Preparation & 5.7 & 7.6 & 0.0 & 15.7 & 0.9 \\
\hline Dung Application & 0.0 & 1.0 & 0.0 & 3.6 & 7.8 \\
\hline Irrigation & 0.0 & 10.2 & 7.6 & 4.0 & 7.1 \\
\hline Sowing & 6.5 & 8.0 & 0.0 & 0.0 & 9.3 \\
\hline Weeding & 22.2 & 6.4 & 5.6 & 4.4 & 2.9 \\
\hline Transplanting of paddy & 1.7 & 0.3 & 54.2 & 12.1 & 55.1 \\
\hline Harvesting & 55.2 & 59.4 & 19.2 & 8.0 & 6.5 \\
\hline Threshing & 6.5 & 3.2 & 20.8 & 51.3 & 1.8 \\
\hline Buying of Inputs & 2.2 & 1.8 & 0.0 & 0.0 & 0.3 \\
\hline Sale of crop & 0.0 & 0.5 & 0.0 & 0.0 & 1.2 \\
\hline Hiring of labour & 0.0 & 1.6 & 0.0 & 0.0 & 100.0 \\
\hline Total & 100.0 & 100.0 & 100.0 & 100.0 & \\
\hline
\end{tabular}

Source: Based on Table 5

\section{Total Family Labour Used in All Crops}

In this section, the use of family and hired labour in agricultural activities in cultivation of all crops is discussed. Table 9 shows person days spent by family and hired labour in cultivation per hectare. Family labour in agriculture comes to 433-persondays per hectare, out of which 90 -persondays are contributed by women and 341-persondays by men. The contribution of hired female and male workers is 53.6 and 100.6-persondays respectively.

Harvesting of crops and cleaning of sugarcane account for roughly one-fourth of family female labour time each (Table 10). Weeding accounts for about one sixth of family female labour. In case of male family workers also, harvesting and cleaning of sugarcane are the most important activities followed by irrigation. Cleaning of cane accounts for 60 percent of labour time of female hired labour and 40 per cent of labour time of male hired labour. 
Table 9. Person days per hectare of family and hired labour by activity

\begin{tabular}{|l|c|c|c|c|c|}
\hline \multirow{2}{*}{\multicolumn{1}{|c|}{ Type of Activity }} & \multicolumn{2}{|c|}{ Family Labour } & \multicolumn{2}{c|}{ Hired labour } & \multirow{2}{*}{ Total } \\
\cline { 2 - 5 } & Females & Males & Females & Males & 17.0 \\
\hline LandPreparation & 2.4 & 11.5 & 0.0 & 3.1 & 13.0 \\
\hline Dung Spraying & 1.2 & 9.1 & 0.0 & 2.7 & 8.1 \\
\hline Seed collecting/Cutting & 1.3 & 3.5 & 1.2 & 2.0 & 3.7 \\
\hline Transplantation & 0.4 & 0.3 & 2.4 & 0.6 & 24.5 \\
\hline Irrigation & 0.4 & 20.7 & 0.0 & 3.4 & 30.1 \\
\hline Sowing & 2.6 & 24.0 & 0.0 & 3.5 & 36.6 \\
\hline Weeding & 14.9 & 13.7 & 3.5 & 4.6 & 18.2 \\
\hline Digging & 1.9 & 8.7 & 3.2 & 4.3 & 7.0 \\
\hline Fertilizing & 0.1 & 4.8 & 0.0 & 2.1 & 4.1 \\
\hline Pesticide & 0.1 & 3.2 & 0.0 & 0.8 & 22.9 \\
\hline Binding of cane & 0.4 & 14.0 & 0.0 & 8.5 & 175.0 \\
\hline Cleaning of cane & 23.4 & 78.7 & 32.2 & 40.7 & 55.1 \\
\hline Loading & 8.5 & 27.3 & 5.6 & 13.8 & 104.9 \\
\hline Harvesting & 24.3 & 71.8 & 3.3 & 5.5 & 15.0 \\
\hline Threshing & 3.0 & 6.6 & 1.3 & 4.1 & 7.8 \\
\hline Cleaning Grain/Storage & 6.1 & 0.0 & 0.9 & 0.8 & 8.3 \\
\hline Buying of Inputs & 0.7 & 7.6 & 0.0 & 0.0 & 30.1 \\
\hline Sales of crop & 0.0 & 30.1 & 0.0 & 0.0 & 5.8 \\
\hline Hiring of labour & 0.5 & 5.3 & 0.0 & 0.0 & 587.1 \\
\hline Total & 92.2 & 340.9 & 53.6 & 100.4 & \\
\hline & & & & & \\
\hline
\end{tabular}

Source: Field Survey

Table 10.Percentage distribution of person days per hectare in all crops

\begin{tabular}{|l|c|c|c|c|c|}
\hline \multirow{2}{*}{\multicolumn{1}{|c|}{ Type of Activity }} & \multicolumn{2}{c|}{ Family Labour } & \multicolumn{2}{c|}{ Hired labour } & \multirow{2}{*}{ Total } \\
\cline { 2 - 5 } & Females & Males & Females & Males & 2.9 \\
\hline LandPreparation & 2.6 & 3.4 & 0.0 & 3.1 & 2.2 \\
\hline Dung Spraying & 1.3 & 2.7 & 0.0 & 2.6 & 1.4 \\
\hline Seed collecting/Cutting & 1.4 & 1.0 & 2.3 & 2.0 & 0.6 \\
\hline Transplantation & 0.4 & 0.1 & 4.5 & 0.6 & 4.2 \\
\hline Irrigation & 0.4 & 6.1 & 0.0 & 3.4 & 5.1 \\
\hline Sowing & 2.8 & 7.0 & 0.0 & 3.5 & 6.2 \\
\hline Weeding & 16.2 & 4.0 & 6.4 & 4.5 & 3.1 \\
\hline Digging & 2.1 & 2.6 & 6.0 & 4.3 & 1.2 \\
\hline Fertilizing & 0.1 & 1.4 & 0.0 & 2.1 & 0.7 \\
\hline Pesticide & 0.1 & 0.9 & 0.0 & 0.8 & 3.9 \\
\hline Binding of cane & 0.4 & 4.1 & 0.0 & 8.5 & 29.8 \\
\hline Cleaning of cane & 25.4 & 23.1 & 60.1 & 40.5 & 9.4 \\
\hline Loading & 9.2 & 8.0 & 10.4 & 13.7 & 17.9 \\
\hline Harvesting & 26.4 & 21.1 & 6.2 & 5.5 & 2.6 \\
\hline Threshing & 3.3 & 1.9 & 2.4 & 4.1 & 1.3 \\
\hline Cleaning Grain/Storage & 6.6 & 0.0 & 1.7 & 0.8 & 1.4 \\
\hline Buying of Inputs & 0.8 & 2.2 & 0.0 & 0.0 & 5.1 \\
\hline Sales of crop & 0.0 & 8.8 & 0.0 & 0.0 & 1.0 \\
\hline Hiring of labour & 0.5 & 1.6 & 0.0 & 0.0 & 100.0 \\
\hline Total & 100.0 & 100.0 & 100.0 & 100.0 & \\
\hline
\end{tabular}

Source: Based on Table 9

\section{Share of Family and Hired Labour in Agricultural Activities}

In this section, the share of family and hired labour (casual+permanent) in agriculture on the sample farms is analysed. Table 11 shows the share of family and hired labour in sugarcane crop by activity. Sugarcane is a relatively labour intensive crop and absorbs more family as well as hired labour as compared to other crops. About 67 percent labour hours are contributed by family members in cultivation of sugarcane and 33 percent by hired labour. The major activities for which hired labour is used are binding, cleaning and loading of cane, seed 
collection, sowing and weeding. It may also be observed that the use of hired female labour is slightly more in cleaning of cane, seed collection, weeding and transport of cane.

Table 11. Share of family and hired labour in sugarcane (percent)

\begin{tabular}{|l|c|c|c|c|c|c|}
\hline \multirow{2}{*}{\multicolumn{1}{|c|}{ Type of Activity }} & \multicolumn{3}{c|}{ Family Labour } & \multicolumn{3}{c|}{ Hired labour } \\
\cline { 2 - 6 } & Females & Males & Total & Females & Males & Total \\
\hline Land Preparation & 11.9 & 59.4 & 71.3 & 0.0 & 28.7 & 28.7 \\
\hline Dung Application & 9.2 & 71.6 & 80.7 & 0.0 & 19.3 & 19.3 \\
\hline Seed collecting/Cutting & 16.1 & 43.5 & 59.6 & 15.4 & 25.0 & 40.4 \\
\hline Irrigation & 5.4 & 66.8 & 72.2 & 0.0 & 27.8 & 27.8 \\
\hline Sowing & 2.3 & 83.1 & 85.4 & 0.0 & 14.6 & 14.6 \\
\hline Weeding & 31.0 & 35.9 & 66.9 & 14.1 & 19.0 & 33.1 \\
\hline Digging & 13.4 & 61.5 & 75.0 & 0.0 & 25.0 & 25.0 \\
\hline Fertilizing & 2.1 & 77.1 & 79.2 & 0.0 & 20.8 & 20.8 \\
\hline Pesticide & 3.7 & 74.6 & 78.4 & 0.0 & 21.6 & 21.6 \\
\hline Binding of cane & 1.7 & 61.1 & 62.8 & 0.0 & 37.2 & 37.2 \\
\hline Cleaning of cane & 13.4 & 45.0 & 58.3 & 18.4 & 23.2 & 41.7 \\
\hline Transport of Cane & 13.4 & 48.1 & 61.5 & 13.6 & 24.9 & 38.5 \\
\hline Buying of Inputs & 5.4 & 94.6 & 100.0 & 0.0 & 0.0 & 0.0 \\
\hline Sales of crop & 0.0 & 100.0 & 100.0 & 0.0 & 0.0 & 0.0 \\
\hline Hiring of labour & 11.5 & 88.5 & 100.0 & 0.0 & 0.0 & 0.0 \\
\hline Total & 11.6 & 55.1 & 66.8 & 11.8 & 21.5 & 33.2 \\
\hline
\end{tabular}

Source: Based on Table 3

Table 12 shows the percentage share of hired and family labour in different activities of wheat crop. In wheat crop, around 20 percent of work is done by hired labourers. Hired labour contributes 49 percent work related to fertilizer application and 20-30 percent work related to sowing, harvesting and threshing and carrying chaff from field to home. Hired labour is not used for weeding, which is done mainly by female family labour. Hired female labour is only used in harvesting, threshing and storage of grain.

Table 12. Share of family and hired labour in wheat cultivation (percent)

\begin{tabular}{|l|c|c|c|c|c|c|}
\hline \multirow{2}{*}{\multicolumn{1}{|c|}{ Type of Activity }} & \multicolumn{3}{c|}{ Family Labour } & \multicolumn{3}{c|}{ Hired labour } \\
\cline { 2 - 7 } & Females & Males & Total & Females & Males & Total \\
\hline Land Preparation & 14.7 & 58.8 & 73.5 & 0.0 & 26.5 & 26.5 \\
\hline Dung Application & 10.9 & 67.0 & 77.9 & 0.0 & 22.1 & 22.1 \\
\hline Irrigation & 1.0 & 82.0 & 83.0 & 0.0 & 17.0 & 17.0 \\
\hline Sowing & 16.3 & 60.5 & 76.7 & 0.0 & 23.3 & 23.3 \\
\hline Weeding & 100.0 & 0.0 & 100.0 & 0.0 & 0.0 & 0.0 \\
\hline Fertilizing & 0.0 & 51.3 & 51.3 & 0.0 & 48.7 & 48.7 \\
\hline Pesticide Spraying & 0.0 & 85.1 & 85.1 & 0.0 & 14.9 & 14.9 \\
\hline Harvesting & 29.2 & 51.4 & 80.7 & 6.5 & 12.8 & 19.3 \\
\hline Threshing & 20.5 & 52.0 & 72.5 & 6.0 & 21.5 & 27.5 \\
\hline Carrying Grain to house & 23.9 & 57.4 & 81.3 & 0.0 & 18.7 & 18.7 \\
\hline Carrying chaff to house & 20.1 & 52.2 & 72.2 & 0.0 & 27.8 & 27.8 \\
\hline Cleaning Grain & 82.2 & 0.0 & 82.2 & 0.0 & 17.8 & 17.8 \\
\hline Storage & 73.5 & 0.0 & 73.5 & 26.5 & 0.0 & 26.5 \\
\hline Buying of Inputs & 0.0 & 100.0 & 100.0 & 0.0 & 0.0 & 0.0 \\
\hline Sale of crop & 0.0 & 100.0 & 100.0 & 0.0 & 0.0 & 0.0 \\
\hline Hiring of labour & 11.1 & 88.9 & 100.0 & 0.0 & 0.0 & 0.0 \\
\hline Total & 26.2 & 54.0 & 80.2 & 3.8 & 16.1 & 19.8 \\
\hline
\end{tabular}

Source: Based on Table 5

Table 13 shows the share of hired and family labour in different activities of other crops. Hired labour contributes less than 10 percent of total labour in other crops and most of the operations are done by family labour. Hired labour is used for specific purposes. About 80 percent of transplantation, 44 percent of threshing and 17 percent of dung application is done by hired labour. Hired female labour is extensively involved in transplanting of paddy crop. 
Table 13. Share of family and hired labour in cultivation of other crops (percent)

\begin{tabular}{|l|c|c|c|c|c|c|}
\hline \multirow{2}{*}{\multicolumn{1}{|c|}{ Type of Activity }} & \multicolumn{3}{c|}{ Family Labour } & \multicolumn{3}{c|}{ Hired labour } \\
\cline { 2 - 7 } & Females & Males & Total & Females & Males & Total \\
\hline Land Preparation & 15.0 & 76.0 & 91.0 & 0.0 & 9.0 & 9.0 \\
\hline Dung Application & 0.0 & 83.3 & 83.3 & 2.7 & 16.7 & 19.4 \\
\hline Irrigation & 0.0 & 95.1 & 95.1 & 0.0 & 2.2 & 4.9 \\
\hline Sowing & 17.9 & 82.1 & 100.0 & 0.0 & 0.0 & 0.0 \\
\hline Weeding & 46.2 & 49.8 & 96.0 & 2.0 & 2.0 & 4.0 \\
\hline Transplanting of paddy & 11.6 & 8.7 & 20.3 & 62.2 & 17.4 & 79.7 \\
\hline Harvesting & 19.5 & 78.8 & 98.2 & 1.2 & 0.6 & 1.8 \\
\hline Threshing & 19.6 & 36.5 & 56.1 & 10.7 & 33.2 & 43.9 \\
\hline Buying of Inputs & 23.8 & 76.2 & 100.0 & 0.0 & 0.0 & 0.0 \\
\hline Sale of crop & 0.0 & 100.0 & 100.0 & 0.0 & 0.0 & 0.0 \\
\hline Hiring of labour & 0.0 & 100.0 & 100.0 & 0.0 & 0.0 & 0.0 \\
\hline Total & 19.4 & 73.0 & 92.5 & 3.3 & 4.2 & 7.5 \\
\hline
\end{tabular}

Source: Based on Table 7

\section{Share of Female Labour in Total Labour Use in Agriculture}

Now, the contribution of female labour in total agricultural work on the sample farms can be analysed. Table 14 shows use of family and hired labour per farm by sex. On average 1029persondays were spent on agriculture on the sample farms. Out of this 107 persondays were contributed by female family members and 133 persondays by female hired labour. The contribution of male family members was 429-persondays and that of hired male labour 360persondays.

Table 14. Total labour use in different agricultural activities by sex (person days / per farm)

\begin{tabular}{|l|c|c|c|c|c|}
\hline \multirow{2}{*}{ Type of Activity } & \multicolumn{2}{|c|}{ Family Labour } & \multicolumn{2}{c|}{ Hired Labour } & Total \\
\cline { 2 - 5 } & Female & Male & Female & Male & Persondays \\
\hline LandPreparation & 2.1 & 10.3 & 0.0 & 4.2 & 16.5 \\
\hline Dung Spraying & 1.5 & 10.6 & 0.0 & 4.8 & 16.9 \\
\hline Irrigation & 0.7 & 36.4 & 0.0 & 8.1 & 45.2 \\
\hline Sowing & 2.1 & 12.5 & 0.0 & 17.0 & 31.6 \\
\hline Weeding & 17.1 & 16.8 & 16.4 & 18.0 & 68.4 \\
\hline Transplantation & 0.4 & 0.3 & 5.6 & 1.2 & 7.4 \\
\hline Fertilizing & 0.1 & 7.1 & 0.0 & 3.8 & 11.0 \\
\hline Pesticide & 0.1 & 4.4 & 0.0 & 1.8 & 6.3 \\
\hline Seed collection/Cutting & 2.1 & 5.8 & 5.3 & 7.5 & 20.7 \\
\hline Digging & 3.2 & 14.5 & 0.0 & 17.9 & 35.7 \\
\hline Binding of cane & 0.7 & 23.3 & 0.0 & 55.3 & 79.2 \\
\hline Cleaning of cane & 38.8 & 130.7 & 82.5 & 152.0 & 404.0 \\
\hline Loading & 17.6 & 48.4 & 6.7 & 17.1 & 89.8 \\
\hline Harvesting & 2.2 & 4.9 & 0.8 & 4.1 & 11.9 \\
\hline Threshing & 11.7 & 39.2 & 14.9 & 46.2 & 112.1 \\
\hline Cleaning Grain/Storage & 5.2 & 0.0 & 0.0 & 0.0 & 5.2 \\
\hline Buying of Inputs & 0.6 & 8.9 & 0.5 & 0.8 & 10.9 \\
\hline Sales of crop & 0.0 & 49.2 & 0.0 & 0.0 & 49.3 \\
\hline Hiring of labour & 0.7 & 6.0 & 0.0 & 0.5 & 7.3 \\
\hline Total & 106.9 & 429.3 & 132.7 & 360.3 & 1029.2 \\
\hline
\end{tabular}

\section{Source: Field Study}

Table 15 shows percentage share of family and hired labour in total labour use in agriculture on sample farms. Female family labour contributes 10.4 percent of total labour use in agriculture and hired female labour contributes 12.9 percent. Thus, roughly one fourth of agricultural labour is contributed by women workers in the study region. Male family workers contribute 41.7 percent of total agricultural work and hired male workers 23.3 percent.

The contribution of different groups varies from activity to activity. The work related to cleaning and storage of grains is done entirely by female family members. The next most important work performed by them is weeding where they contribute 25 percent of labour. In harvesting and loading of crops, female family members contribute one fifth of the total labour. Hired female workers share 75 percent of transplantation work and about one fourth of work 
related to weeding and seed collecting and cutting of sugarcane. Hired male workers participate in nearly all activities contributing more than half of labour required for sowing, digging and binding of cane. More than one third work related to threshing, cleaning of cane, harvesting and fertilizing is also done by them.

Table 15. Percentage share of family and hired labour in total labour use per farm

\begin{tabular}{|l|c|c|c|c|c|c|}
\hline \multirow{2}{*}{ Type of Activity } & \multicolumn{2}{|c|}{ Family Labour } & \multicolumn{2}{c|}{ Hired Labour } & \multicolumn{2}{c|}{ Total Labour } \\
\cline { 2 - 7 } & Female & Male & Female & Male & Female & Male \\
\hline LandPreparation & 12.7 & 62.0 & 0.0 & 25.3 & 12.7 & 87.3 \\
\hline Dung Spraying & 8.9 & 62.7 & 0.0 & 28.4 & 8.9 & 91.1 \\
\hline Irrigation & 1.5 & 80.5 & 0.0 & 17.9 & 1.5 & 98.5 \\
\hline Sowing & 6.6 & 39.6 & 0.0 & 53.8 & 6.6 & 93.4 \\
\hline Weeding & 25.0 & 24.6 & 24.0 & 26.3 & 49.0 & 50.9 \\
\hline Transplantation & 5.3 & 4.0 & 74.7 & 16.0 & 80.0 & 20.0 \\
\hline Fertilizing & 0.9 & 64.5 & 0.0 & 34.5 & 0.9 & 99.1 \\
\hline Pesticide & 1.6 & 69.8 & 0.0 & 28.6 & 1.6 & 98.4 \\
\hline Seed collecting/Cutting & 10.1 & 28.0 & 25.6 & 36.2 & 35.7 & 64.3 \\
\hline Khudai & 9.0 & 40.6 & 0.0 & 50.1 & 9.0 & 90.8 \\
\hline Bandhai & 0.9 & 29.4 & 0.0 & 69.8 & 0.9 & 99.2 \\
\hline Chilai & 9.6 & 32.4 & 20.4 & 37.6 & 30.0 & 70.0 \\
\hline Loading & 19.6 & 53.9 & 7.5 & 19.0 & 27.1 & 72.9 \\
\hline Harvesting & 18.5 & 41.2 & 6.7 & 34.5 & 25.2 & 75.6 \\
\hline Threshing & 10.4 & 35.0 & 13.3 & 41.2 & 23.7 & 76.2 \\
\hline Cleaning Grain/Storage & 100.0 & 0.0 & 0.0 & 0.0 & 100.0 & 0.0 \\
\hline Buying of Inputs & 5.5 & 81.7 & 4.6 & 7.3 & 10.1 & 89.0 \\
\hline Sale of crop & 0.0 & 99.8 & 0.0 & 0.0 & 0.0 & 99.8 \\
\hline Hiring of labour & 9.7 & 83.3 & 0.0 & 6.9 & 9.7 & 90.3 \\
\hline Total & 10.4 & 41.7 & 12.9 & 35.0 & 23.3 & 76.7 \\
\hline
\end{tabular}

Source: Field Study

Table 16 shows total labour use on sample farms by major crops. Total person days per farm comes to 840 in case of sugarcane, 111 in case of wheat and 75 in case of other crops. Family female labour provides 70-person days on sugarcane, 23.5-persondays on wheat and 13.8persondays on other crops. The corresponding figures for male family labour are 329,48 and 52 persondays, respectively. Sugarcane accounts for over 80 percent of total labour input on sample farms (Table 17). Wheat accounts for 11 percent labour input and other crops around 7 percent.

Table 16. Total labour used in different crops per farm (in person days)

\begin{tabular}{|l|c|c|c|c|c|}
\hline \multirow{2}{*}{ Type of Activity } & \multicolumn{2}{|c|}{ Family Labour } & \multicolumn{2}{c|}{ Hired Labour } & \multirow{2}{*}{ Total } \\
\cline { 2 - 5 } & Female & Male & Female & Male & 839.85 \\
\hline Sugarcane & 69.54 & 329.06 & 118.74 & 322.51 & 111.14 \\
\hline Wheat & 23.46 & 48.31 & 5.97 & 33.4 & 75.36 \\
\hline Other Crops & 13.81 & 51.91 & 5.73 & 3.9 & 1026.35 \\
\hline Total & 106.81 & 429.28 & 130.44 & 359.81 & \\
\hline
\end{tabular}

Source: Field Study

Table 17.Percent share of different crops in total labour use per farm

\begin{tabular}{|l|c|c|c|c|c|}
\hline \multirow{2}{*}{ Type of Activity } & \multicolumn{2}{|c|}{ Family Labour } & \multicolumn{2}{c|}{ Hired Labour } & \multirow{2}{*}{ Total } \\
\cline { 2 - 5 } & Female & Male & Female & Male & \\
\hline Sugarcane & 65.1 & 76.7 & 91.0 & 89.6 & 81.8 \\
\hline Wheat & 22.0 & 11.3 & 4.6 & 9.3 & 10.8 \\
\hline Other Crops & 12.9 & 12.1 & 4.4 & 1.1 & 7.3 \\
\hline Total & 100.0 & 100.0 & 100.0 & 100.0 & 100.0 \\
\hline
\end{tabular}

Source: Field Study

Table 18 shows the contribution of female labour in total labour input on sample farms by major crops. Female family labour contributes about 10 percent of total labour input in agriculture on sample farms. They contribute 21 percent of labour input in wheat crop and about 18 percent in other crops, while their contribution in sugarcane crop is only 8.3 percent, even though they spend about 65 percent of their labour time in agriculture on this crop. Male 
family members contribute about 40 percent of labour input in sugarcane and wheat and almost 70 percent of labour input in other crops. Hired labour contributes over half of labour input in sugarcane and about one third input in wheat. Its share in other crops is nominal.

Table 18. Percent share of female family labour in different crops in total labour use by major crops

\begin{tabular}{|l|c|c|c|c|c|}
\hline \multirow{2}{*}{ Type of Activities } & \multicolumn{2}{|c|}{ Family Labour } & \multicolumn{2}{c|}{ Hired Labour } & Total \\
\cline { 2 - 5 } & Female & Male & Female & Male & \\
\hline Sugarcane & 8.3 & 39.2 & 14.1 & 38.4 & 100.0 \\
\hline Wheat & 21.1 & 43.5 & 5.4 & 30.1 & 100.0 \\
\hline Other Crops & 18.3 & 68.9 & 7.6 & 5.2 & 100.0 \\
\hline Total & 10.4 & 41.8 & 12.7 & 35.1 & 100.0 \\
\hline
\end{tabular}

Source: Field Study

\section{Use of Labour by Size of Holdings}

Earlier studies have found a negative association between the use of female labour and size of holding. This section investigates this association for our sample farms. Generally, the size of holding is divided into four categories, i.e. marginal (below 1 ha.), small (between 1 and 2 ha.), medium (between 2 and 4 ha.) and large (above 4 ha.). Table 19 shows the average persondays of family and hired labour used in cultivation of crops on the sample farms by sex and crops by size of holdings. It can be seen ' from the table that the use of family female labour declines sharply from 200-person days on marginal farms to 31-persondays on large farms. This is also true for male family workers. The inverse relationship between family labour and size of holdings is observed for individual crops also. On the other hand, the use of hired female as well as male labour rises with the increase in the size of holdings.

The marginal farmers with their small land base and lack of other resources try to reduce their paid out cost by putting more family labour on their farms. On the other hand, in case of larger holdings the need of employing hired labour is more as the task cannot be managed by family labour only. Their capacity to pay is also more. Table 20 shows that the share of family labour (both male and female) in total labour use declines sharply from 85 percent on marginal farms to 46.6 percent in case of large farms. The corresponding figures for family female labour are 25 and 6 percent respectively.

Table 19.Use of family and hired labour by size of land holdings on sample farms (persondays perfarm)

\begin{tabular}{|l|c|c|c|c|c|c|c|c|c|}
\hline \multirow{2}{*}{$\begin{array}{c}\text { Size of } \\
\text { Holding }\end{array}$} & \multicolumn{3}{|c|}{ Family labour } & \multicolumn{3}{c|}{ Hired Labour } & \multicolumn{3}{c|}{ Total labour } \\
\cline { 2 - 10 } & Female & Male & Total & Female & Male & Total & Female & Male & Total \\
\hline Marginal & 104.42 & 237.79 & 342.21 & 33.02 & 58.58 & 91.60 & 137.44 & 296.37 & 433.81 \\
\hline Small & 49.61 & 168.69 & 218.30 & 49.05 & 86.24 & 135.29 & 98.66 & 254.93 & 353.58 \\
\hline Medium & 37.51 & 136.58 & 174.09 & 53.72 & 94.62 & 148.34 & 91.23 & 231.20 & 322.43 \\
\hline Large & 11.28 & 117.94 & 129.22 & 62.00 & 164.04 & 226.04 & 73.28 & 281.98 & 355.26 \\
\hline All Holdings & 50.71 & 165.25 & 215.95 & 49.45 & 100.87 & 150.32 & 100.15 & 266.12 & 366.27 \\
\hline \multicolumn{8}{|c|}{ Wheat } \\
\hline Marginal & 44.16 & 64.68 & 108.84 & 3.00 & 12.38 & 15.38 & 47.16 & 77.05 & 124.22 \\
\hline Small & 27.07 & 44.12 & 71.19 & 3.58 & 16.72 & 20.30 & 30.65 & 60.84 & 91.49 \\
\hline Medium & 18.36 & 30.43 & 48.78 & 5.42 & 17.96 & 23.37 & 23.77 & 48.38 & 72.16 \\
\hline Large & 11.58 & 24.84 & 36.42 & 8.09 & 22.00 & 30.09 & 19.67 & 46.84 & 66.51 \\
\hline All Holdings & 25.29 & 41.02 & 66.31 & 5.02 & 17.26 & 22.29 & 30.31 & 58.28 & 88.59 \\
\hline \multicolumn{8}{|c|}{ Other crop } \\
\hline Marginal & 51.64 & 114.79 & 166.43 & 2.32 & 2.68 & 5.00 & 53.96 & 117.46 & 171.43 \\
\hline Small & 28.33 & 66.40 & 94.73 & 1.63 & 2.50 & 4.13 & 29.96 & 68.90 & 98.85 \\
\hline Medium & 14.22 & 68.79 & 83.01 & 5.33 & 5.68 & 11.01 & 19.55 & 74.47 & 94.02 \\
\hline Large & 8.34 & 74.00 & 82.34 & 8.00 & 20.00 & 28.00 & 16.34 & 94.00 & 110.34 \\
\hline All Holdings & 25.63 & 80.99 & 106.63 & 4.32 & 7.72 & 12.03 & 29.95 & 88.71 & 118.66 \\
\hline \multicolumn{8}{|c|}{ All Crops } \\
\hline Marginal & 200.23 & 417.25 & 617.48 & 38.34 & 73.63 & 111.97 & 238.57 & 490.88 & 729.45 \\
\hline Small & 105.01 & 279.20 & 384.21 & 54.25 & 105.46 & 159.72 & 159.27 & 384.66 & 543.93 \\
\hline Medium & 70.09 & 235.79 & 305.88 & 64.47 & 118.26 & 182.73 & 134.56 & 354.05 & 488.61 \\
\hline Large & 31.20 & 216.79 & 247.98 & 78.09 & 206.04 & 284.13 & 109.28 & 422.82 & 532.11 \\
\hline All Holdings & 101.63 & 287.26 & 388.89 & 58.79 & 125.85 & 184.64 & 160.42 & 413.11 & 573.53 \\
\hline Source: Fie/d Study & \multicolumn{8}{|c|}{} \\
\hline
\end{tabular}


The contribution of women to agricultural work in the study area which specializes in sugarcane cultivation is higher than their contribution revealed by earlier studies in wheat growing northern states of Punjab and Haryana (Agarwal, 1981; Bhalla, 1989). However, the involvement of women in the study area is lower than their involvement in the rice growing regions of south India (Mies, 1985; Chen, 1989). The study also confirms the inverse relationship between size of holding and use of female labour observed in the earlier studies. The findings about the work segregation by sexes are also in line with the findings of the earlier studies.

Table 20. Share of family labour and hired labour in agriculture by size of land holdings on sample farms (percent)

\begin{tabular}{|c|c|c|c|c|c|c|c|c|c|}
\hline \multirow{2}{*}{$\begin{array}{c}\text { Size of } \\
\text { Holdings }\end{array}$} & \multicolumn{3}{|c|}{ Family labour } & \multicolumn{3}{|c|}{ Hired Labour } & \multicolumn{3}{|c|}{ Total labour } \\
\hline & Female & Male & Total & Female & Male & total & Female & Male & total \\
\hline \multicolumn{10}{|c|}{ Sugarcane } \\
\hline Marginal & 24.07 & 54.81 & 78.89 & 7.61 & 13.50 & 21.11 & 31.68 & 68.32 & 100.00 \\
\hline Small & 14.03 & 47.71 & 61.74 & 13.87 & 24.39 & 38.26 & 27.90 & 72.10 & 100.00 \\
\hline Medium & 11.63 & 42.36 & 53.99 & 16.66 & 29.35 & 46.01 & 28.30 & 71.70 & 100.00 \\
\hline Large & 3.17 & 33.20 & 36.37 & 17.45 & 46.17 & 63.63 & 20.63 & 79.37 & 100.00 \\
\hline Total & 13.84 & 45.12 & 58.96 & 13.50 & 27.54 & 41.04 & 27.34 & 72.66 & 100.00 \\
\hline \multicolumn{10}{|c|}{ Wheat } \\
\hline Marginal & 35.55 & 52.07 & 87.62 & 2.42 & 9.97 & 12.38 & 37.97 & 62.03 & 100.00 \\
\hline Small & 29.59 & 48.22 & 77.81 & 3.91 & 18.28 & 22.19 & 33.50 & 66.50 & 100.00 \\
\hline Medium & 25.44 & 42.17 & 67.61 & 7.51 & 24.89 & 32.39 & 32.95 & 67.05 & 100.00 \\
\hline Large & 17.41 & 37.35 & 54.76 & 12.16 & 33.08 & 45.24 & 29.57 & 70.43 & 100.00 \\
\hline Total & 28.55 & 46.30 & 74.84 & 5.67 & 19.49 & 25.16 & 34.22 & 65.78 & 100.00 \\
\hline \multicolumn{10}{|c|}{ Other crop } \\
\hline Marginal & 30.13 & 66.96 & 97.08 & 1.35 & 1.56 & 2.92 & 31.48 & 68.52 & 100.00 \\
\hline Small & 28.66 & 67.17 & 95.83 & 1.64 & 2.53 & 4.17 & 30.31 & 69.69 & 100.00 \\
\hline Medium & 15.13 & 73.16 & 88.29 & 5.67 & 6.04 & 11.71 & 20.80 & 79.20 & 100.00 \\
\hline Large & 7.56 & 67.07 & 74.62 & 7.25 & 18.13 & 25.38 & 14.81 & 85.19 & 100.00 \\
\hline Total & 21.60 & 68.26 & 89.86 & 3.64 & 6.50 & 10.14 & 25.24 & 74.76 & 100.00 \\
\hline \multicolumn{10}{|c|}{ Total Agriculture } \\
\hline Marginal & 27.45 & 57.20 & 84.65 & 5.26 & 10.09 & 15.35 & 32.71 & 67.29 & 100.00 \\
\hline Small & 19.31 & 51.33 & 70.64 & 9.97 & 19.39 & 29.36 & 29.28 & 70.72 & 100.00 \\
\hline Medium & 14.34 & 48.26 & 62.60 & 13.19 & 24.20 & 37.40 & 27.54 & 72.46 & 100.00 \\
\hline Large & 5.86 & 40.74 & 46.60 & 14.68 & 38.72 & 53.40 & 20.54 & 79.46 & 100.00 \\
\hline Total & 17.72 & 50.09 & 67.81 & 10.25 & 21.94 & 32.19 & 27.97 & 72.03 & 100.00 \\
\hline
\end{tabular}

Source: Based on Table 19

\section{Conclusion}

The major findings of the paper are summarized below:

(i) Women's participation in agricultural activities is quite widespread in the study area and women engage in most of the agricultural operations except ploughing.

(ii) Female family labour contributes about 10 percent of total labour input in agriculture on the sample farms. They contribute 21 percent of labour input in wheat crop and about 18 percent in other crops, while their contribution in sugarcane crop is only 8.3 percent, even though they spend about 65 percent of their labour time in agriculture on this crop.

(iii) Women's participation in agriculture depends on the labour requirement for various crops. Almost three-fourth of total family labour is spent on sugarcane crop. Sugarcane accounts for 65 percent of female family labour and 76.5 percent of male family labour. Only 21 percent of female family labour and 11 percent of male family labour is spent on wheat crop. Other crops account for about 13 percent of family labour.

(iv) There exists clear segregation in the agricultural activities by sex. Weeding, cleaning grain and storage of grain are done exclusively by women. Activities related to land preparation, ploughing, irrigation, spraying fertilizer and pesticides are generally done by men. Other agricultural operations such as seed collection, dung spraying, sowing, 
transplanting, harvesting, threshing, and carrying the grains to home are jointly done by the men and woman. But all market related activities like buying agricultural inputs and hiring labour and sale of output are exclusively done by the male members, generally the head of the family.

(v) The use of both male and female labour declines sharply with the rise in the holding size. On the other hand, the use of hired labour rises with the increases with the size of holdings. The marginal farmers with small land base and lack of resources try to reduce their paid out cost by putting more family labour on their farm.

The analysis revealed that even though household women participate widely in agricultural activities, they are treated as reserve labour and called for work whenever need of additional labour on farm increases. Women are assigned work which is regarded as less skilled and involves light manual work. Male household workers are engaged in tasks which are regarded as more skilled and superior requiring use of machines and new inputs. Men also monopolise all market related activities and thereby retain control on income generation. Hence, the work of female household workers remains invisible and unpaid. It does not provide them greater access to money but adds to their already heavy burden of domestic duties and care of animals. Women do not have ownership of land and are not regarded as cultivators by government agencies. As a result, they get no access to extension and publicly provided services to the agricultural sector.

It is high time that women workers in agriculture should be given due recognition in public policy. As the State of Food and Agriculture Report 2010-11 observes "closing the gender gap in agriculture would generate significant gains for the agriculture sector and for society" (FAO 2011 , p. 5). It is, therefore, suggested that special training courses should be organized for them to inform about new technology and agricultural practices. Research should also focus on the activities performed by women in agriculture and develop suitable implements and machines which may reduce their work burden at home and farm. Women should also be given entitlement over land so that they can access credit and inputs for agriculture. Male cultivators should also be sensitized about the importance of women's work in agriculture and give them suitable monetary compensation for their work. This will go a long way in reducing gender gap in agriculture.

\section{Acknowledgment}

This paper is based on the Ph.D. thesis of the Author. I am thankful to Prof. A.K. Singh, Former Director of the Giri Institute of Development Studies, and Ph.D. Supervisor, for their guidance and valuable suggestions to complete the paper. I am also thankful to the ICSSR for financial support during the Ph.D. Work.

\section{Note}

The present paper is a part of the Author's Doctoral Research awarded in 2012. The primary survey was conducted by the researcher herself during the year 2008-09 that lasted for almost 4 months. The survey was started in November \&December 2008(the time of wheat sowing and sugarcane harvesting) and further continued from April \&May 2009(which is the time of wheat harvesting and sugarcane sowing). The detailed information was collected in Hindi language from the main female of the family who actively participated in the different activities. The researcher has used 'recall method' to collect the time spent by her/him on different activities of various crops grown by the family. 


\section{References}

Achanta, I.D. (1982). "Role of women in agricultural development”, Kurukshetra, 31(2), $15-17$.

Agarwal, B.(1981). "Agricultural Mechanization and Labour Use: A Disaggregated Approach," International LabourReview, 120(1), 115-127.

Agarwal, B.(1983). "Mechanisation in Indian Agriculture: An Analytical Study Based on the Punjab". Delhi: Allied Publishers.

Agarwal, B.(1984). "Rural Women and High Yielding Variety Rice Technology", Economic and Political Weekly, Review of Agriculture, A39-A52.

Agarwal, B.(1985), "Work Participation of Rural Women in Third World - Some Data and Conceptual Biases", Economic and Political Weekly, Review of Agriculture, 20 (51-52), A-155-A-64.

Agrawal, Chandrasekhar,(2015). "Short Term Migrants in India: Characteristics, Wages and Work Transition”, Working Paper 2015-07, Mumbai: Indira Gandhi Institute of Development Research (IGIDR).

Anker, R. (1983). "Female Labour Force Participation In developing Countries: critique of Current Definitions and Data Collection Techniques methods". International Labour Review, 122(6).

Arputhamuthy, S. (1990).Women, Work and Discrimination. New Delhi: Ashish Publishing House.

Arya, S.L. \& Madhukar, R.M. (1988). "Impact of Watershed Management on Role of Women in Agriculture". Abstracts, International Conference on Farm Women, Indian Council of Agricultural Research, New Delhi.

Bala, N. (2010). "Selective Discrimination Against Women in Indian Agriculture - A Review". Agriculture Review, 31(3).

Baliyan, K.\&Kumar, S. (2014). "Participation of Farm Household Women in Agricultural Activities and Its Determinants: AStudy in Western Uttar Pradesh”. Indian Journal of Labour Economics, 57(3), 327-341.

Bhalla, S. (1989). "Technological Change and Women Workers: Evidence from the Expansionary Phase in Haryana Agriculture, Economic and Political Weekly,24(43), WS67-WS78.

Bhandari, G.\& Reddy, B.V.C. (2015). "Impact of Out-Migration on Agriculture and Women Work Load: An Economic Analysis of Hilly Regions of Uttarakhand, India". Indian Journal of Agriculture Economics, 70(3).

Boserup, E. (1970). Women’s Role in Economic Development. New York, NY: George Allen and Unwin.

Chakravorthy, K\&Tewari B.C. (1977). "Regional Variation in Women's Employment: a Case study of Five Village in Three Indian States”, AProgramme on Women's Studies, ICSSR New Delhi (Mimeo).

Chakravorthy,S. (1975). "Women Power in Agriculture”. Kurukshetra, 50(4).

Chand, R,Sidhu, D.S.\&Kaul J.L.(1985). "Impact of Agricultural Modernization on Labour Use Pattern in Punjab with Special Reference to Women Labour". Indian Journal of Agricultural Economics, 40(3) JulySeptember

Chen, M. (1989). "Women's Work in Indian Agriculture by Agro-Ecologic Zones: Meeting Needs of Landless and Land-Poor Women". Economic and Political Weekly, 24(43), WS79-WS89.

Chhattopadhyaya, M. (1982). "Role of Female Labour in Indian Agriculture”. Social Scientist, 10(6), 43-58.

Reddy, C.K.\&Devendra, D. (2010). "Socio-Economic Conditions of Agricultural Women Labour in Andhra Pradesh: A Case Study of Karimnagar District". International Journal of Business Economics and Management Research, 2(3).

Chowdhry, P. (1993)."High Participation And Low Evaluation: Women And Work In Rural Haryana". Economic and Political Weekly, 28(52), A-135-A-147

Deere, C. (2005). "The Feminization of Agriculture? Economic Restructuring in Rural Latin America". Occasional Paper No. 1, United Nation Research Institute for Social Development, Geneva. www.unrisd.org/publications/opgp

Dak, T.K. \& Sharma M.L. (1988). "Social Frame-work of Female Labour Participation in Ru-ral Sector" in T M Dak(ed.), Women and Work in Indian Society, Delhi: Manohar Publications, 26-48.

Dev, S.M. (2004). "Female Work Participation and Child Labour: Occupational Data from NFHS". Economic and Political Weekly, 39(7), 736-744.

Dhillon, G. (1980). “The Changing Role of Rural Women”, Social Change, 11(3). 
Dutta, L.N. \& Sharma, N. (1985). "Contribution of Female Labour in Agriculture: A Case Study of Ranchi District (Bihar)". Indian Journal of Agricultural Economics, 40(3).

Duvvury. (1989). "Women in Agriculture: A Review of the Indian Literature", Economics and Political Weekly, 24(43), WS96-WS112.

Eapen, M. (1994). "Rural non-agricultural employment in Kerala: Some emerging tendencies", Economics and Political Weekly, 29(21), 1285-1296.

FAO (2011). The State of Food and Agriculture, Food and Agriculture Organisation of the United Nations, Rome. http://www.fao.org/docrep/013/i2050e/i2050e00.pdf

Hirway, I.(2002). "Indian Experience of Time Use Survey" Proceedings of the National Seminar on Applications of Time Use Statistics, Organized by Central Statistical Organisation and UNIFEM held at New Delhi .

Hirway, I.(2009). "Time Use Surveys: Concept, Classification and Related Issues Lessons from the Indian Pilot Time Use Survey", http://www.cepal.org/mujer/noticias/noticias/3/22983/IndiraEUTStwsa-09.pdf

Hirway, I.(2015). "Unpaid Work and the Economy: Linkages and their Implications”. Indian Journal of Labour Economics, 58(1), 1-21.

Hirway, I.\& Roy, A.K.(1999). "Women in Rural Economy: The Case of India". Indian Journal of Agriculture Economics, 54(3).

Kanchi, A. (2010), "Women Workers in Agriculture: Expanding Responsibilities and Shrinking Opportunities", ILOAsia-Pacific Working paper series, Sub-regional Office New Delhi.

Krishna Raj, M. (1990). "Women's Work in Indian Census: Beginnings of Change". Economic and Political Weekly, 25(48/49), 2663-2672.

Krishna Raj, M.\& Shah, A. (2014). "Women workers in Agriculture: Visible and Invisible”, in Maithreyi Krishna Raj \& Amita Shah (ed.) 'Women in Agriculture', series of 'State of the Indian farmer: A Millennium Study'. Vol27, published by Department of Agriculture and Cooperation, Ministry of Agriculture, Government of India, New Delhi.

Cornhiel, S.L. (2006). "Feminization of Agriculture: Trends and Driving Forces." Background Paper for the World Development Report 2008.http://siteresources. worldbank.org/ INTWDRS/ Resources/ 4773651327599046334/8394679-1327599874257/LastarriaCornhiel_FeminizationOfAgri.pdf

Mencher, J, \& Saradamoni P. K. (1982). "Muddy Feet, Dirty Hands - Rice Production and Female Agriculture Labour," Economic and Political Weekly, 17(52), A149-A167.

Mies, M. (1980). Indian Women and Patriarchy. New Delhi: Concept Publishing Co.

Mies, M.Kumari, L,\& Kumari, K. (1986).Indian Women in Subsistence and Agricultural Labour, ILO, Geneva.

Muller, R.D.(1985). “Women's Work in Third World Agriculture”.ILO, Geneva.

NSSO (2011-12). "Employment and Unemployment Report”, 2011-12, Published by Ministry of Statistics and Programme Implementation, Government of India, New Delhi.

Patel, V.(1989). "Problem Pertaining to Women's Work Paid, Unpaid, Employment, Unemployment". A collection of Papers presented at the UN-INSTRAW - GOIDWCD - SNDT - National Workshop and Indicators, Changing Perspectives.

Pattnaik,I., Dutt, K., Lockie, S. \& Pritchard, B. (2017). "The feminization of agriculture or the feminization of agrarian distress? Tracking the trajectory of women in agriculture in India", Journal of the Asia Pacific Economy, 23(1),138-155.

Patnaik, S.C. \& Devi, S. (1986). "An Assessment of Women's Economic Contribution to the Farm Sector, A Micro Level Study”. Journal of Rural Development, 5(4), 480-490.

Reddy, N.D. \& Venkatanrayana, M. (2013). "Declining Labour Use in Agriculture : A Case of Rice Cultivation in Andhra Pradesh" National Institute of Rural Development (NIRD), Hyderabad (Munich Personal RePEc Archive).

Roy, A. (1993). "Women Agricultural Labour in Bihar: A District Wise Analysis of Census Data".In Alakh. N. Sharma and Seema, Singh (ed), Women and Work Changing Scenario of India, Delhi: B.R. Publishing Corporation.

Saradamoni, K. (1987), "Labour, Land and Rice Production - Women Involvement in Three States". Economic and Political Weekly, 22(17), WS-2-WS-6. 
Saradamoni, K. (1991). "Filling the Rice Bowl, Women in Paddy Cultivation”. Hyderabad: Sangam Books.

Sen, G. (1983a). "Women's Work and Women Agricultural Labourers: A Study of the Indian Census", Working Paper No.159, Centre for Development Studies, Thiruvananthapuram

Sen, G. (1983b) "Women Agricultural Workers - Regional Variations in Incidence and Employment". Working PaperNo. 168, Centre for Development Studies, Thiruvananthapuram.

Sen, G. (1983c). "Paddy Production Processing and Women Workers in India - The South Versus the Northeast”. Working Paper No. 186, Centre for Development Studies Thiruvananthapuram.

Sen, G. (1987). "Women Agricultural Labourers: Regional Variations in Incidence and Employment". paper presented at the National Workshop on Women in Agriculture, September 23-24, New Delhi.

Sen, G. \& Sen, C. (1985). "Women's Domestic Work and Economic Activity, Results from NSS". Economic and Political Weekly, 20(17).

Mohini, S.R. (1982). Female Labour in Agriculture: A Case of Punjab, Department of Sociology, Punjab University, Chandigarh.

Singh, A.V. \& Bhati, J.P. (1985), "Women in Hill Agricultural: A Case Study of Himachal Pradesh". Indian Journal of Agricultural Economics, 11(3).

Sree, B.K. (2001). "Women in Agriculture: An Evaluation of the Central Scheme in Palakkad District (Kerala)". Thiruvananthapuram: Discussion Paper No. 3, Kerala research Programme on Local Level development centre for development Studie.

Srivastava, N.\&Srivastava. R. (2010). "Women, Work, and Employment Outcomes in Rural India". Economic \& Political Weekly, 155(28).

Sunder, P. (1981). "Characteristics of Female Employment: Implications of Research and Policy". in Economic and Political Weekly, 16(19).

Suryawanshi, S.D. \& Kopase, P.M. (1985). "Impact of Ghod Irrigation Project on Employment of Female Agricultural Labour". Indian Journal of Agricultural Economics, 11(3).

Swaminathan, M.S. (1985). "Imparting a Rural Women User's Perspective of to Agricultural Research and Development. Philippines: IRRI.

Tumbe, C. (2014). "Missing Men, Migration and Labor Markets: Evidence from India", paper presenting in South Asia Research Network's (SARNET) workshop on 'Labor Markets, Employment and Inclusive Growth in South Asia' in IHD, New Delhi in December 2013. http://www.ihdindia. org/sarnet/ module1/TumbeMissingMenMigrationandLaborMarketsinIndia.pdf

Unni, J. (1992). “Women's Participation in Indian Agriculture”, Oxford and IBH Publishing Co. Pvt. Ltd., New Delhi, Mumbai, Kolkata.

Tuteja, U. (2000). Contribution of Female Agricultural Workers in Family Income and their Status in Haryana. Indian Journal of Agriculture Economics, 55(2),32-67.

Verma, S.K. (1992), "Women in Agriculture - A Socio-Economic Analysis”. New Delhi: Concept Publishing Company.

Visaria, P. (1999), "Level and Pattern of Female Employment in India", in T. S. Papola, Alalkh N. Sharma (ed.) 'Gender and Employment in India'. New Delhi: Vikas Publishing House.

World Bank (2012), “Gender Equality and Development". World Development Report 2012, https:// siteresources.worldbank.org/INTWDR2012/Resources/7778105-1299699968583/7786210-1315936 222006/Complete-Report.pdf 